\title{
Persistent anovulatory follicles in the mare
}

\author{
Simone Först, Hedwig Niederstucke and Hans-Otto Hoppen \\ ZA für Chemische Analytik und Endokrinologie, Tierärztliche Hochschule Hannover
}

\begin{abstract}
Summary
In this study the hormonal levels in the follicular fluid of a group of mares $(n=20)$ with persistent anovulatory follicles were compared to a control group $(n=11)$ of mares with normal preovulatory follicles. Follicular fluid was collected following transabdominal puncture of the follicles or transvaginally with the aid of ultrasound for hormone measurement. Of the mares with persistent anovulatory follicles, $72 \%$ of the cases occurred in March and April and only 28\% of the punctures were carried out in May, June and July. The persistent follicles showed echogenic particles in the follicular lumen on ultrasound in $71.4 \%$ of all cases. The concentrations of oestradiol, progesterone and inhibin B were significantly lower in the follicular fluid of the anovulatory group as compared to the controls. The concentration of oestradiol was positively correlated with that of inhibin in the follicular fluid of the anovulatory group, whereas in the control group there was a negative correlation between inhibin and progesterone. Of the hormones in peripheral plasma, testosterone was significantly higher in patients as compared to controls $(0.02 \mathrm{vs} .0 .01 \mathrm{ng} / \mathrm{ml}, \mathrm{p}<0.05)$; other hormone concentrations were similar in both groups. The lower concentrations of oestradiol, inhibin, and progesterone in the follicular fluid of the anovulatory group suggest an impairment of granulosa cell function in this condition. Puncture of the persistent follicles is a suitable treatment for affected mares resulting in a normal oestrous cycle.
\end{abstract}

Keywords: mare, persistant anovulatory follicle, oestradiol, inhibin B, progesterone

\section{Persistierende anovulatorische Ovarfollikel bei der Stute}

In der vorliegenden Studie wurden Hormonspiegel in der Follikelflüssigkeit von Stuten mit persistierenden anovulatorischen Follikeln ( $\mathrm{n}=20$ ) mit denen von normalen Stuten $(n=11)$ mit präovulatorischen Follikeln verglichen. Follikel wurden transabdominal oder transvaginal unter Ultraschallkontrolle aspiriert. Die Mehrzahl der Patienten (72\%) wurde im März und April diagnostiziert, nur 28\% der Fälle wurden von Mai bis Juli vorgestellt. In 71,4\% der Fälle wurden echogene Partikel in den persistierenden Follikeln nachgewiesen. Die Konzentrationen von Östradiol, Progesteron und Inhibin-B waren in der Follikelflüssigkeit der Patienten signifikant niedriger als in den Kontrollen. In der Gruppe mit anovulatorischen Follikeln war Östradiol positiv mit Inhibin-B korreliert, während bei den Kontrollen eine negative Korrelation zwischen Progesteron und Inhibin vorlag. Im peripheren Plasma war Testosteron bei Patienten signifikant höher $(0,02 \mathrm{ng} / \mathrm{ml} \mathrm{gegen} \mathrm{0,01} \mathrm{ng/ml,}$ $p<0,05)$ als bei Kontrollen; die anderen Hormone im Plasma unterschieden sich nicht. Die niedrigen Konzentrationen von Östradiol, Progesteron und Inhibin-B in der Follikelflüssigkeit der anovulatorischen Stuten deutet auf eine mögliche Störung der Funktion der Granulosazellen. Die Follikelpunktion erweist sich als wirksame Therapie der betroffenen Tiere.

Schlüsselwörter: Reproduktion, Stute, persitierende anovulatorische Follikel, Östradiol, Inhibin B, Progesteron

\section{Introduction}

Persistent anovulatory follicles in the mare have been considered to be rare in the past, however recent data from the literature suggests a higher incidence (Kaiser et al. 1999, McCue and Squires 2002). Due to the limited time span of the equine breeding season persistent anovulatory follicles constitute a serious medical and economical problem for the breeder. Unlike in cattle or swine, there is no generally accepted diagnostic criteria for this condition in the mare, nor is there sufficient information about the potential endocrine causes. The aim of the present study was to establish meaningful criteria for the diagnosis of persistent anovulatory follicles, and to analyse follicular fluid and peripheral plasma for possible endocrine changes associated with the impaired follicular development.

\section{Material and methods}

Animals

Twenty mares were diagnosed with persistent anovulatory follicles according to the following diagnostic criteria: the domi- nant follicle had an average diameter $>40 \mathrm{~mm}$; there was no softening of the follicular wall; no change in follicular shape; no corpus luteum was visible on ultrasound; and the endometrial oedema was reduced or missing. Eleven mares with normal preovulatory follicles served as controls. They all showed good oestrus signs for several days; had a preovulatory follicle with an average diameter of $>40 \mathrm{~mm}$, a tendency to softening of the follicular wall and the start of regeneration of the endometrial oedema.

\section{Follicular puncture}

Follicular fluid was aspirated either by transabdominal puncture of the follicles after manual fixation of the ovary against the ipsilateral abdominal wall (Kaiser et al. 1999), or by the ultrasound guided transvaginal method described by Brück et al. (1992). Follicular fluid and peripheral plasma samples were stored frozen $\left(-20^{\circ}\right)$ until assayed for hormones.

Hormone assays: Oestradiol, progesterone and testosterone were analysed using specific radioimmunoassays as described elsewhere (Behrens et al. 1993, Günzel-Apel et al. 1990). Inhibin B was measured using an ELISA (inhibin-B dimer assay kit, ultra sensitive, code MCA1312KZZ, Serotec 
Ltd, Oxford, UK) according to the manufacturer's instructions; assay performance characteristics are described by Groome et al. (1996).

\section{Results}

Twenty mares presenting with various fertility problems met the above criteria for persistent anovulatory follicles and were included in the study. The majority of cases (15) presented in March and April, and only 5 cases were picked up in May, June and July, indicating a seasonal component in the etiology. Follicular fluid could not be collected in 2 mares due to technical problems, 2 mares had 2 persistent follicles on one ovary, and 1 mare presented twice within 10 days. The average diameter of all persistent follicles was $57.6 \pm 27.9 \mathrm{~mm}$, the average volume of follicular fluid collected was $76.1 \pm$ $72.2 \mathrm{ml}$ with 17 out of 23 follicles showing echogenic particles on ultrasound. Of the control group, follicles were collected in April, June and July, had an average diameter of $44.5 \pm 0.4 \mathrm{~mm}$, an average aspiration volume of $70.9 \pm$ $23.9 \mathrm{ml}$, and did not have any echogenic particles on ultrasound.

The hormone concentrations in follicular fluid are collated in Table 1 for patients, and Table 2 for controls. The mean hormone levels in peripheral plasma of patients and controls, taken at the time of follicle puncture are given in Table 3.

The concentrations of oestradiol, inhibin-B and progesterone were significantly higher in the follicular fluid of controls than in patients $(p<0.01,<0.01,<<0.05$, respectively). Oestra-

Tab 1 Hormones in follicular fluid of mares with persistent anovulatory follicles

Hormonkonzentrationen in der Follikelflüssigkeit von Stuten mit persistierenden anovulatorischen Follikeln

\begin{tabular}{|c|c|c|c|c|c|}
\hline Mare & sample & $\begin{array}{c}\text { oestradiol } \\
(\mathrm{ng} / \mathrm{ml})\end{array}$ & progesterone $(\mathrm{ng} / \mathrm{ml})$ & $\begin{array}{c}\text { testosterone } \\
(\mathrm{ng} / \mathrm{ml})\end{array}$ & $\begin{array}{c}\text { Inhibin-B } \\
(\mathrm{ng} / \mathrm{ml})\end{array}$ \\
\hline 1 & 1.1 & - & - & - & - \\
\hline 2 & 2.1 & 2.3 & 40.9 & 0.31 & 0.55 \\
\hline 3 & 3.1 & 135.2 & 4 & 0.08 & 5 \\
\hline 4 & 4.1 & - & - & - & - \\
\hline 5 & 5.1 & 0.46 & 7.3 & 0.03 & 0.345 \\
\hline 6 & 6.1 & 18.6 & 41.75 & 0.53 & 0.134 \\
\hline 7 & 7.1 & 0.12 & 0.2 & 0.01 & 0.005 \\
\hline & 7.2 & 2.900 .00 & 10 & 6.8 & 5.1 \\
\hline 8 & 8.1 & 0.01 & 2.9 & 0.01 & 0.004 \\
\hline & 8.2 & 317.8 & 14.1 & 0.33 & 3.8 \\
\hline 9 & 9.1 & 386.1 & 5.6 & 0.96 & 7.2 \\
\hline 10 & 10.1 & 3.514 .80 & 35.8 & 5.7 & 0 \\
\hline & 10.2 & 167.5 & 4.7 & 0.22 & 19.15 \\
\hline 11 & 11.1 & 2.921 .50 & 38.5 & 3.8 & 28.0 \\
\hline 12 & 12.1 & 4.000 .00 & 20.8 & 3.8 & 16.0 \\
\hline 13 & 13.1 & 125.8 & 43.4 & 10.7 & 1.1 \\
\hline 14 & 14.1 & 3.830 .20 & 15.15 & 2.7 & 17.55 \\
\hline & 14.2 & 387 & 5.7 & 0.34 & 11.1 \\
\hline 15 & 15.1 & 1.925 .40 & 10.7 & 1.4 & 2.9 \\
\hline 16 & 16.1 & 24.9 & 1.6 & 2.25 & 10.4 \\
\hline 17 & 17.1 & 17.8 & 7.0 & 18.65 & 11.8 \\
\hline 18 & 18.1 & 0.42 & 7.3 & 0.04 & 3.3 \\
\hline 19 & 19.1 & 4.1 & 7.2 & 13.65 & 0.73 \\
\hline 20 & 20.1 & 13.7 & 32.5 & 0.15 & 0.233 \\
\hline$\times \pm s d$ & & $941 \pm 1425$ & $16.2 \pm 14.7$ & $3.29 \pm 4.92$ & $6.56 \pm 7.62$ \\
\hline
\end{tabular}

Tab 2 Hormones in follicular fluid of control mares Hormonkonzentrationen in der Follikelflüssigkeit von Kontrollstuten

\begin{tabular}{|c|c|c|c|c|c|} 
Mare & sample & $\begin{array}{c}\text { oestradiol } \\
(\mathrm{ng} / \mathrm{ml})\end{array}$ & $\begin{array}{c}\text { progesterone } \\
(\mathrm{ng} / \mathrm{ml})\end{array}$ & $\begin{array}{c}\text { testosterone } \\
(\mathrm{ng} / \mathrm{ml})\end{array}$ & $\begin{array}{c}\text { Inhibin-B } \\
(\mathrm{ng} / \mathrm{ml})\end{array}$ \\
\hline A & A.1 & 5.123 .50 & 20.50 & 3.50 & 23.10 \\
\hline B & B.1 & 781.00 & 40.00 & 2.70 & 1.00 \\
\hline C & C.1 & 5.810 .00 & 40.00 & 5.90 & 13.40 \\
\hline D & D.1 & 3.183 .00 & 16.00 & 1.90 & 30.80 \\
\hline E & E.1 & 4.348 .00 & 27.10 & 2.30 & 18.40 \\
\hline F & F.1 & 2.384 .00 & 37.00 & 2.10 & 24.80 \\
\hline G & G.1 & 2.030 .00 & 35.80 & 2.50 & 15.70 \\
\hline H & H.1 & 5.220 .00 & 36.80 & 4.70 & 17.00 \\
\hline I & I.1 & 2.492 .10 & 31.80 & 6.70 & 22.80 \\
\hline K & K.1 & 4.030 .60 & 9.70 & 3.10 & 21.60 \\
\hline L & L.1 & 1.574 .00 & 28.10 & 1.40 & 21.50 \\
\hline x sd & & 3.361 & 29.4 & 3.35 & 19.10 \\
\hline & & & & & \\
\hline
\end{tabular}

diol was positively correlated with inhibin in the follicular fluid of the anovulatory group, whereas in the control group there was a negative correlation between inhibin and progesterone. In peripheral plasma, testosterone was significantly higher in patients as compared to controls $(0.02$ vs. 0.01 $\mathrm{ng} / \mathrm{ml}, \mathrm{p}<0.05)$; other hormone concentrations were similar in both groups.

None of the mares developed any complications following follicular puncture. Fourteen of 15 patients had normal cycles after the procedure, one showed a prolonged oestrus. Five patients did not return for cycle checks. Sixteen of the mares were inseminated after removal of the persistent follicles, 11 of which resulted in pregnancies. All controls had normal cycles after the puncture.

\section{Discussion}

The present paper describes criteria for the diagnosis of persistent anovulatory follicles in the mare, the treatment of this condition by follicular aspiration, and the attempt to elucidate pathomechanisms by comparing hormone concentrations in the patients follicular fluid with control mares. Both the transabdominal and the ultrasonically guided transvaginal approach appear to be suitable methods for follicular puncture in the mare. The transabdominal method is technically simple, however aspirating follicular fluid is sometimes difficult or incomplete. The transvaginal approach is more precise and reliably results in complete aspiration of the follicular contents, but it requires expensive equipment.

The diagnostic criteria used in this study were similar to those described elsewhere (McCue 1998 and 2000, McCue and Squires 2002, Kaiser et al. 1999), with the difference being that we included follicles containing echogenic particles, whilst others excluded such cases from their studies. As 17 of 23 follicles did contain echogenic material, the inclusion of such cases appears to be reasonable. Furthermore, we feel that the appearance of echogenic material may be result of

Tab 3 Mean hormone concentrations in peripheral plasma Mittlere Hormonkonzentrationen im Plasma

\begin{tabular}{|c|c|c|c|c|c|}
\hline Group & & $\begin{array}{c}\text { oestradiol } \\
(\mathrm{pg} / \mathrm{ml})\end{array}$ & progesterone $(\mathrm{ng} / \mathrm{ml})$ & $\begin{array}{c}\text { testosterone } \\
(\mathrm{ng} / \mathrm{ml})\end{array}$ & $\begin{array}{c}\text { Inhibin-B } \\
(\mathrm{ng} / \mathrm{ml})\end{array}$ \\
\hline patients & $\mathrm{n}=20$ & $13.23 \pm 3.50$ & $2.02 \pm 2.28$ & $0.020 \pm 0.018$ & $<0.02$ \\
\hline controls & $\mathrm{n}=11$ & 9.57 & 3.43 & $0.01 \pm 0$ & $<0.02$ \\
\hline
\end{tabular}


the pathomechanism and thus could be a leading symptom of the condition.

One of the most striking differences is the enormous heterogeneity of follicular hormone concentrations in patients as compared to controls: Oestradiol for example varies from 0.01 to $4000 \mathrm{ng} / \mathrm{ml}$ in patients and only between 781 and $5220 \mathrm{ng} / \mathrm{ml}$ in controls; similar differences are seen for inhibin, progesterone and testosterone. Together with the significantly lower average levels of oestradiol, inhibin and progesterone in patients this could be interpreted as an indication of a variable degree of granulosa cell dysfunction or damage in anovulatory follicles. The follicular oestradiol to testosterone ratio is also reduced (286 in patients vs. 1003 in controls) suggesting a severe loss of aromatase activity.

Inhibins are secreted by granulosa cells of the growing follicles under the control of FSH (Donadeu and Ginther 2001). Their main role during the ovarian cycle is the suppression of FSH secretion by the pituitary (Bergfelt et al. 1991, Findlay 1993). Inhibin secretion increases with the increase in oestradiol concentrations and ceases with the preovulatory LH surge, however rises again briefly around ovulation in the mare (Nagamine et al. 1998). The physiological role of this secundary peak is not clear; it may explain why the average concentration of inhibin- $B$ in control follicles, which in the present study are aspirated immediately before ovulation, is higher than that reported elsewhere for follicles $>30 \mathrm{~mm}$ (Tanaka et al. 2000). Inhibins have been reported to be involved in the occurrence of granulosa cell tumours in mares (Bailey et al. 2002); it would be interesting to compare the concentrations of the inhibin free alpha subunit, which is elevated in granulosa cell tumours, with those in persistent anovulatory follicles.

Insufficient GnRH and LH secretion has been identified as a cause for the development of persistent anovulatory follicles in the bovine (Wiltbank et al. 2002); such data does not exist for the mare. Follicular prostaglandins have been implied in the mechanisms leading to ovulation in many mammals; it would be interesting to speculate about the involvement of $\mathrm{LH}$ and prostaglandins in the pathogenesis of persistent anovulatory follicles in the mare.

\section{Literature}

Bailey M. T., Troedsson M. H. and Wheato J. E. (2002): Inhibin concentrations in mares with granulosa cell tumours. Theriogenology $57,1885-1895$
Behrens C., Aurich J. E., Klug E., Naumann H. and Hoppen H.-O. (1993): Inhibition of gonadotrophin release in mares during the luteal phase of the oestrous cycle by endogenous opioids. J. Reprod. Fertil. 98, 509-514

Bergfeldt D. R., Mann B. G., Schwartz N. B. and Ginther O. J. (1991): Circulating concentrations of immunoreactive inhibin and FSH during estrous cycles of mares. Equine Vet. Sci. 11, 319-322

Brück I., Raun K., Synnestvedt B. and Greve T. (1992): Follicle aspiration in the mare using a transvaginal ultrasound-guided technique. Equine Vet. J. 24, 58-59

Donadeu F. X. and Ginther O. J. (2001): Effect of number and diameter of follicles on plasma concentrations of inhibin and FSH in mares. J. Reprod. Fert., 121, 897-903

Findlay J. K. (1993): An update on the roles of inhibin, activin and follistatin as local regulator of folliculogenesis. Biol. Reprod. 48, $5-23$

Groome N. P., Illingworth P .J., O'Brien M., Pai R., Rodger FE., Mather J. and McNeilly A. S. (1996): Measurement of dimeric Inhibin$B$ throughout the human menstrual cycle. J. Clin. Endo. Metab. 81, 1400-1405

Günzel-Apel A. R., Brinckmann H.-G. und Hoppen H.-O. (1990): Dynamik der LH-und Testosteron-Sekretion bei Beagle-Rüden verschiedener Altersgruppen. Reprod. Dom. Anim. 25, 78-86

Kaiser B., Koene M., Swagemakers J., Bader H. und Hoppen H.-O. (1999): Diagnose, Therapie und endokrinologischew Parameter persistierender Follilkel bei der Stute im Vergleich zu präovulatorischen Follikeln. Tierärzłl. Praxis 27, 180-186

McCue P. M. (1998): Review of ovarian abnormalities in the mare. Proceed. Am. Assoc. Equine Pract. 44, 125-133

McCue P. M. (2000): Diagnosis of ovarian abnormalities. In: Recent advances in equine reproduction. Ball, B.A. (ed) Int. Vet. Inf. Serv., Ithaca, NY

McCue P. M. and Squires E. L. (2002): Persistent anovulatory follicles in the mare. Theriogenology 58, 541-543

Nagamine N., Nambo Y. and Nagata S. (1998): Inhibin secretion in mares. Biol. Reprod. 59, 1392-1398

Tanaka Y., Nagamine N., Nambo Y., Nagata S., Nagaoka K., Tsunoda N., Taniyama H., Yoshihara T., Oikawa M., Watanabe G. and Taya K. (2000): Ovarian secretion of inhibin in mares. J. Reprod. Fert. Suppl. 56, 239-245

Wiltbank M. C., Gumen A. and Sartori R. (2002): Physiological classification of anovulatory conditions in cattle. Theriogenology 57 , $21-52$

Dr. Hans-Otto Hoppen

Institut für Endokrinologie

Tierärztliche Hochschule Hannover

Bischofsholer Damm

hans-otto.hoppen@tiho-hannover.de 